\title{
Overexpression of PD-L1 in Papillary Carcinoma and Its Association with Clinicopathological Variables
}

\author{
Papiller Karsinomda PD-L1'in Aşırı Ekspresyonu ve Klinikopatolojik Değişkenlerle İlişkisi
}

\author{
Servet KOCAÖZ ${ }^{1}$ \\ (D) 0000-0002-0085-2380 \\ Gülay TURAN ${ }^{2}$ \\ (D) 0000-0002-3702-8811
}

${ }^{1}$ Department of General Surgery, Ankara City Hospital, Ankara, Turkey ${ }^{2}$ Department of Medical Pathology, Balikesir University Faculty of Medicine, Balıkesir, Turkey

\section{Corresponding Author Sorumlu Yazar Servet KOCAÖZ servet.kocaoz@gmail.com}

Received / Gelis Tarihi : 16.07.2021 Accepted / Kabul Tarihi : 20.10.2021 Available Online /

Çevrimiçi Yayın Tarihi : 23.11.2021

\begin{abstract}
Aim: Standard treatment may not be sufficient in patients with metastatic papillary thyroid cancer (PTC), and it may be beneficial to add PD-1 agents to the treatment. Therefore, this study was conducted to compare and evaluate the expression of PD-L1 in patients with nodular goiter (NG) and Hashimoto's thyroiditis (HT) within the scope of PTC carcinoma.

Material and Methods: Thirty-five patients from each group who underwent thyroidectomy for NG, HT, and PTC, between January 2011 and December 2017 were identified. Immunohistochemically, an anti-PD-L1 stain was applied by taking new sections from the tissue samples of 105 patients. The histological type, tumour diameter, capsule invasion (CI), and lymphovascular invasion (LVI) were evaluated.

Results: Nine $(25.7 \%)$ of the patients with PTC were defined as classic, $10(28.6 \%)$ as follicular, $6(17.1 \%)$ as oncocytic, $5(14.3 \%)$ as encapsulated, 2 (5.7\%) as solid, $1(2.9 \%)$ tall cell, and $2(5.7 \%)$ as Warthin-like. The expression of PD-L1 in the patients with PTC was significantly higher than in the patients with NG and HT $(\mathrm{p}<0.001)$. There was a significant relationship between the increased PD-L1 expression and staining intensity and presence of thyroid LVI in the patients with PTC ( $\mathrm{p}=0.047)$. In addition, the PD-L1 expression and LVI were observed to be more severe in patients with follicular, tall cell, and oncocytic subtype PTC $(\mathrm{p}=0.011, \mathrm{p}=0.026$, respectively).

Conclusion: It was observed that the PD-L1 expression increased in patients with PTC. PD-L1 expression and LVI were more severe in patients with follicular, tall cell, and oncocytic subtype of PTC.

Keywords: Papillary thyroid carcinoma; Hashimoto thyroiditis; nodular goiter; PD-L1.
\end{abstract}

ÖZ

Amaç: Metastatik papiller tiroid kanserli (papillary thyroid cancer, PTC) hastalarda standart tedavi yeterli olmayabilir ve tedaviye anti-PD-1 ajanların da eklenmesi faydalı olabilir. Bu nedenle bu çalışma, PTC karsinomu kapsamında, nodüler guatr (NG) ve Hashimoto tiroiditi (HT) hastalarında PD-L1 ekspresyonunun karşılaştırılması ve değerlendirilmesi amacıyla yapılmışıır.

Gereç ve Yöntemler: Ocak 2011 ile Aralık 2017 tarihleri arasında, NG, HT ve PTC nedeniyle tiroidektomi yapılmış olan, her hasta grubundan otuz beş hasta belirlendi. 105 hastanın doku örneklerinden yeni kesitler alınarak immünohistokimyasal olarak anti-PD-L1 boyası uygulandı. Histolojik tip, tümör çapı, kapsül invazyon (capsule invasion, CI) ve lenfovasküler invazyon (lymphovascular invasion, LVI) değerlendirildi.

Bulgular: PTC tanısı alan hastaların 9'u (\%25,7) klasik, 10'u $(\% 28,6)$ foliküler, 6's $(\% 17,1)$ onkositik, 5'i $(\% 14,3)$ enkapsüle, 2'si $(\% 5,7)$ solid, 1'i $(\% 2,9)$ uzun hücreli ve 2'si $(\% 5,7)$ Warthin benzeri tip olarak tanımlandı. PTC'li hastalarda PD-L1 ekspresyonu, NG ve HT olan hastalardan anlamlı olarak daha yüksekti $(\mathrm{p}<0,001)$. PTC'li hastalarda artmış PD-L1 ekspresyonu ve boyama yoğunluğu ile tiroid LVI varlığı arasında anlamlı bir ilişki vardı $(\mathrm{p}=0.047)$. Ayrıca foliküler, uzun hücreli ve onkositik alt tip PTC'li hastalarda PD-L1 ekspresyonu ve LVI'nın daha şiddetli olduğu gözlendi (sırasıyla p=0,011, p=0,026).

Sonuç: PTC'li hastalarda PD-L1 ekspresyonunun arttığı gözlendi. Foliküler, uzun hücreli ve onkositik alt tip PTC'li hastalarda PD-L1 ekspresyonu ve LVI'nın daha şiddetli olduğu gözlendi.

Anahtar kelimeler: Papiller tiroid karsinomu; Hashimoto tiroiditi; nodüler guatr; PD-L1. 


\section{INTRODUCTION}

According to 2013 data, the annual thyroid cancer (TC) incidence in the United States (USA) is 14.42 per 100,000, and an increase in the incidence of TC and mortality related to TC rate can be seen over the years (1). Among types of cancer, TC ranks as the $4^{\text {th }}$ most commonly seen type among female in the USA (2). Thyroid follicular epithelial-derived cancers are: papillary, follicular and anaplastic. Other thyroid cancers are those that spread from the medullary thyroid cancer, primary lymphoma, sarcomas, and other organs to the metastases to the thyroid gland (3). The most common of these is papillary TC (PTC), accounting for approximately $80 \%$ of TCs (4). Patients with PTC or follicular TC (FTC), among the types of TC, can often be treated without problem. In patients with medullary TC or anaplastic TC (ATC), the tumour is more aggressive and tends to metastasize earlier (5).

The role of immune control point regulators is to prevent auto-immunity, minimize collateral tissue damage, and modulate the immune system's response in chronic infection. Since most of the immune control points are initiated through the interactions of ligand-receptors, they can easily be blocked by antibodies. In addition, the recombinant form of ligands and/or receptors can be obtained (6). Among the immune checkpoint regulators, the CTLA-4 co-inhibitory receptor was first identified $(7,8)$. However, the most studied was the interaction that occurred between PD-1, which is a T-cell inhibitor receptor, and the PD-L1 (8,9). PD-L1, which is also well-known as CD274, is a glycoprotein that occurs on the cell surface, expressed in various tissues, including tumours. Tumours that express PD-L1 may render the cytotoxic $\mathrm{T}$ lymphocytes (CTL) inactive through the merging of inhibitor receptor and PD-1 (10). The expression of PD-L1 increased due to cancer cells, which is a primary host immune escape system. The discovery of the interaction of binding the PD-1 and PD-L1 resulted in the development of immunotherapy as a novel, inspirational treatment for resistance against cancer. It is promising for aggressive differentiated TC patients and ATC patients to utilize immunotherapy (11).

In the recent literature, immune checkpoint inhibitors have been investigated in aggressive forms of TC $(10,12,13)$. The expression of programmed death-ligand 1 (PD-L1) has been determined to be at a lower rate in PTC patients than in FTC and ATC patients (13). It has been reported that the expression of PD-L1 has been higher in patients who had lymph node metastases (10). It has been reported that there is no difference in the expression of PD-L1 in PTC patients who have and do not have lymphocytic thyroiditis (LT) $(10,13)$. In another study, it was reported that the expression of PD-L1 was higher in PTC patients with LT, but there was no difference between the stage of the disease and the PD-L1 expression (14). This study was conducted to analyze the expression of PD-L1 in patients with nodular goiter (NG), Hashimoto's thyroiditis (HT), and PTC and the relation with clinicopathological characteristics.

\section{MATERIAL AND METHODS}

In this study, 35 patients from the NG, HT, and PTC groups were identified by analyzing the histopathological reports of patients who underwent thyroidectomy between January 2011 and December 2017 at Balıkesir Atatürk State Hospital. Necessary permission for the study was obtained from Balıkesir University Medical Faculty Clinical Research Ethics Committee (114, decision dated 28 August 2019). Patients with micro-carcinoma were not included in the study while identifying the patients in the PTC group. The thyroidectomy samples of 105 patients in total were obtained from the pathology archive and re-examining the new sections. These pathology samples were sealed in paraffin after fixation in $10 \%$ neutral buffered formaldehyde. Sections of a thickness of 4 microns were sliced from the samples; they were stained with hematoxylin and eosin. To confirm the previous diagnosis, they were re-examined under a routine light microscope. The prognostic parameters were re-evaluated and recorded concerning the PTC status of the patients. Afterwards, immunohistochemical PDL-1 stain was applied to the new sections taken from tissue samples of the patients in the NG, HT, and PTC groups (Figure 1a, 1b, and $1 \mathrm{c})$. The recovery of antigen was performed through using $\mathrm{CC} 1$, which is an antigen intake solution (as default; pH 8.0) (ref. 950 CC124, Ventana Medical Systems, Inc. Tucson, AZ, ABD). The samples were incubated using the PD-L1 (E1J2J, Cell Signaling Technology, Inc., Danvers MA, 1:100 dilution) monoclonal antibodies at $37^{\circ} \mathrm{C}$ for 32 min. The OptiView DAB Immunohistochemical Retaining Kit (Ventana) and OptiView Amplification Kit (Ventana) were used for visualization for $12 \mathrm{~min}$. The staining process was performed for 120 min in a VENTANA BenchMark ultra-auto slide staining device (Roche Group, Basel, Switzerland) at $90^{\circ} \mathrm{C}$ according to the manufacturer protocols within the user manual for antibodies.

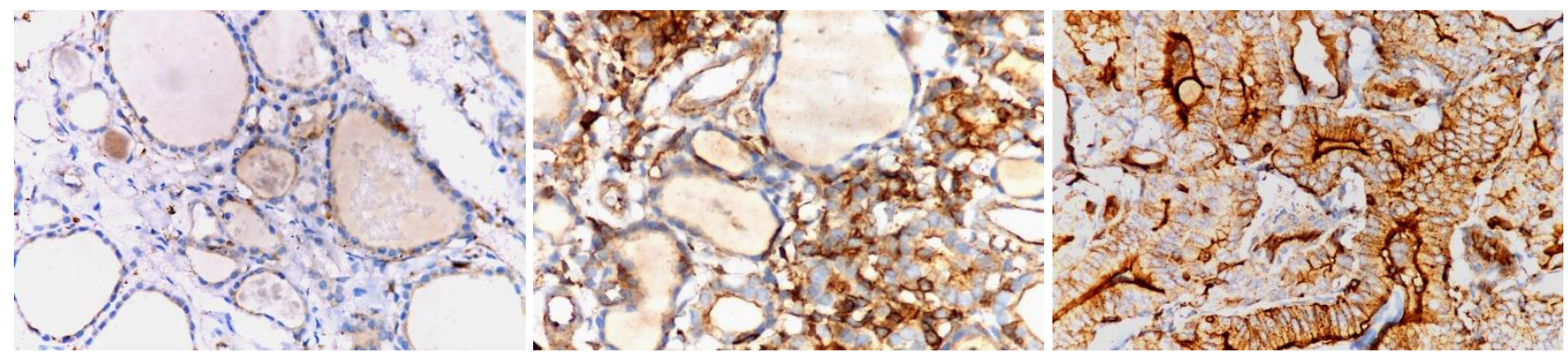

Figure 1. a) Poor expression of PDL-1 in the thyroid follicular epithelial cells in the nodular colloidal goiter, x200. b) Moderate expression of PDL-1 in the thyroid follicular epithelial cells, despite strong expression in the lymphoid cells in HT, x200. c) Increased strong PDL-1 expression in the thyroid follicular epithelial cells in a PTC, x400. 
An experienced pathologist interpreted the staining results of the immunohistochemical PD-L1. Evaluation of the PDL1 expression was semi quantitatively scored according to the staining density that could be separated from the background density (complete staining, and/or partial staining, circumferential staining and/or linear staining) of the membrane of the plasma and cytoplasmic staining. The scoring system was designed based on a scale that ranged from 0 to $3+$, in which 0 indicated negative (meaning that there were 0 positive cells), $1+$ indicated low (meaning that there was less than $25 \%$ positive cells), $2+$ indicated medium (meaning that there were $25 \%$ to $50 \%$ positive cells), and $3+$ indicated high (meaning that there was more than $50 \%$ positive cells). The patient's clinical information, such as age, sex, serum thyroid auto-antibody levels, radiological findings, and treatment method data, were obtained from their medical records.

\section{Statistical Analysis}

The data analyses in this study were performed using the SPSS software program (25.0, IBM Corp., Armonk, NY). Shapiro-Wilk test was used to analyze normality assumption for numerical variables. Numbers, percentage, mean, and standard deviation or median, interquartile range (IQR), and minimum-maximum values were used to present descriptive statistics. The Mann-Whitney $U$ test was used in comparison of tumour diameter in terms of lymphovascular invasion (LVI) and capsule invasion (CI). The Kruskal-Wallis test was used to compare tumour diameter between PD-L1 levels. The Pearson chi-square and Fisher-Freeman-Halton test was used to analyze the difference between the groups in PD-L1 staining scores.

\section{RESULTS}

The mean age of the patients was 53.6 $\pm 9.01,47.82 \pm 13.2$, and 50.26 \pm 15.51 years in the NG, HT, and PTC groups, respectively. Moreover, $21(60 \%)$ of the participants in the NG group and $25(71.4 \%)$ of the HT and PTC groups were female. Anti-TPO (thyroid peroxidase) and anti-TG (thyroglobulin) levels of serum thyroid autoantibodies were higher than laboratory reference values in patients in the HT group. In the radiological findings of the patients who were operated in our hospital, multinodular goiter or the presence of a giant nodule in the thyroid were detected. In the neck ultrasonography examination performed on patients with malignant fine-needle aspiration biopsy (FNAB), the presence of cervical lymph nodes with pathological appearance was determined in 7 patients. It was observed that a patient who had a lateral neck dissection and a patient who had a central lymph node dissection were re-operated because of the detection of metastatic lymph nodes in the follow-up. In this study, $80 \%$ cytoplasmic and $4 \%$ membranous PD-L1 staining was detected in cases with the expression of PD-L1 level. In this study, three patients with PTC developing on HT was detected. In the histopathological evaluation, 9 (25.7\%) of the patients diagnosed with PTC were defined as classic, $10(28.6 \%)$ were defined as follicular, $6(17.1 \%)$ were defined as oncocytic, $5(14.3 \%)$ were defined as encapsulated, $2(5.7 \%)$ were defined as solid, 1 (2.9\%) were defined as tall cell, and $2(5.7 \%)$ were defined as Warthin-like. The tumour diameter of $18(51.4 \%)$ of the patients was between 1 and $2 \mathrm{~cm}, 13(37.1 \%)$ was between 2.1 and $4 \mathrm{~cm}$, and $4(11.4 \%)$ was over $4.1 \mathrm{~cm}$. When evaluating the patients with PTC within the scope of thyroid CI, $10(28.6 \%)$ of the patients had CI, while 25 $(71.4 \%)$ did not. When the PTC patients were evaluated for LVI, 7 (20\%) of the patients had LVI, while $28(80 \%)$ of the patients did not. Of the patients with lymph node metastasis (LNM), seven patients underwent central lymph node dissection (CLND) and total thyroidectomy. In addition to CLND, two other patients also underwent lateral lymph node dissection (LLND). Furthermore, postoperative radioactive iodine (RAI) treatment was given to all of these patients.

Differences in the expression of PD-L1 level were determined to be statistically significant between these groups $(\mathrm{p}<0.001$, Table 1). When PD-L1 expression was compared between the groups with the Bonferroni method, the expression of PD-L1 level was found to be significantly higher than the NG group, both in the HT group and in the PTC group $(\mathrm{p}<0.001)$. Similarly, PD-L1 expression in the PTC group was significantly higher than in the HT group $(\mathrm{p}<0.001)$. When patients with PTC were evaluated in terms of thyroid CI with PD-L1 expression, no significant difference was found $(\mathrm{p}=0.194)$. However, when patients with PTC were assessed in terms of thyroid LVI with the expression of PD-L1 level, the difference was determined to be significant $(\mathrm{p}=0.047$, Table 2$)$. When the significance of LVI between the groups was compared with the Bonferroni method, it was found that the significant difference between the groups was due to patients with PTC with severe PD-L1 expression. In addition, when a comparison was conducted between the tumour diameter according to the expression of PD-L1 level, it was determined that there was no significant difference between the tumour diameter according to the Kruskal-Wallis test results $(\mathrm{p}=0.165)$. Median tumour diameter was $1.8 \mathrm{~cm}$ in patients without LVI, and $3.3 \mathrm{~cm}$ in patients with LVI. In addition, median tumour diameter was $1.5 \mathrm{~cm}$ in patients without $\mathrm{CI}$, and $4 \mathrm{~cm}$ in patients with CI. A significant relationship was determined between the increase in the tumour size and the CI and LVI via the Mann-Whitney $U$ test, $(p<0.001$ and $p=0.022$, respectively, Table 3). Notably, the PD-L1 expression and LVI were observed to be more severe in patients with follicular, tall cell, and oncocytic subtype PTC ( $\mathrm{p}=0.011$ and $\mathrm{p}=0.026$, respectively, Table 4).

Table 1. PD-L1 expression in the NG, HT, and PTC groups

\begin{tabular}{ccccc}
\hline & NG & HT & PTC & p \\
& $(\mathbf{n = 3 5})$ & $(\mathbf{n = 3 5})$ & $(\mathbf{n = 3 5})$ & $\mathbf{p}$ \\
\hline PD-L1 Staining & & & & \\
Weak & $34(97.1)$ & $18(51.4)$ & $5(14.3)$ & \\
Middle & $1(2.9)$ & $17(48.6)$ & $22(62.9)$ & $<\mathbf{0 . 0 0 1}$ \\
Severe & $0(0.0)$ & $0(0.0)$ & $8(22.9)$ & \\
\hline PD-L1: programmed death-ligand 1, NG: nodular & goiter, HT: Hashimoto's
\end{tabular}
thyroiditis, PTC: papillary thyroid cancer

Table 2. Comparison of anti-PD-L1 staining score and LVI

\begin{tabular}{cccc}
\hline & $\begin{array}{c}\text { LVI (-) } \\
(\mathbf{n = 2 8})\end{array}$ & $\begin{array}{c}\text { LVI (+) } \\
(\mathbf{n = 7})\end{array}$ & $\mathbf{p}$ \\
\hline PD-L1 Staining & & & \\
Weak & $5(17.9)$ & $0(0.0)$ & \\
Middle & $19(67.9)$ & $3(42.9)$ & $\mathbf{0 . 0 4 7}$ \\
Severe & $4(14.3)$ & $4(57.1)$ & \\
\hline PD-L1: programmed death-ligand 1, LVI: lymphovascular invasion &
\end{tabular}


Table 3. Comparison of the tumour diameter with the LVI and CI

\begin{tabular}{llcccccc}
\hline & & $\mathbf{n}$ & Median & IQR & Min-Max & Mean Rank & p \\
\hline LVI & & & & & & & \\
& Negative & 28 & 1.8 & 1.65 & $1.2-4.5$ & 16.02 & $\mathbf{0 . 0 2 2}$ \\
& Positive & 7 & 3.3 & 3.13 & $2.5-6.0$ & 25.93 & \\
\hline CI & & & & & & & \\
& Negative & 25 & 1.5 & 0.80 & $1.2-3.4$ & 13.34 & $<\mathbf{0 . 0 0 1}$ \\
& Positive & 10 & 4 & 1.58 & $2.5-6.0$ & 29.65 &
\end{tabular}

LVI: lymphovascular invasion, CI: capsule invasion, IQR: interquartile range

Table 4. Comparison of PTC subgroups in terms of anti-PD-L1 staining and LVI

\begin{tabular}{|c|c|c|c|c|c|c|c|c|}
\hline & $\begin{array}{c}\text { Follicular } \\
(\mathbf{n}=10)\end{array}$ & $\begin{array}{c}\text { Classic } \\
(n=9)\end{array}$ & $\begin{array}{c}\text { Oncocytic } \\
(n=6)\end{array}$ & $\begin{array}{c}\text { Tall-cell } \\
(\mathbf{n}=1)\end{array}$ & $\begin{array}{c}\text { Encapsulated } \\
(\mathbf{n}=5)\end{array}$ & $\begin{array}{l}\text { Solid } \\
(n=2)\end{array}$ & $\begin{array}{l}\text { Warthin-like } \\
\quad(n=2)\end{array}$ & p \\
\hline \multicolumn{9}{|l|}{ PD-L1 Staining } \\
\hline Weak & $0(0.0)$ & $1(11.1)$ & $3(50.0)$ & $0(0.0)$ & $1(20.0)$ & $0(0.0)$ & $0(0.0)$ & \multirow{3}{*}{0.011} \\
\hline Middle & $4(40.0)$ & $8(88.9)$ & $2(33.3)$ & $0(0.0)$ & $4(80.0)$ & $2(100)$ & $2(100)$ & \\
\hline Severe & $6(60.0)$ & $0(0.0)$ & $1(16.7)$ & $1(100)$ & $0(0.0)$ & $0(0.0)$ & $0(0.0)$ & \\
\hline \multicolumn{9}{|l|}{ LVI } \\
\hline Negative & $5(50.0)$ & $9(100)$ & $5(83.3)$ & $0(0.0)$ & $5(100)$ & $2(100)$ & $2(100)$ & \multirow{2}{*}{0.026} \\
\hline Positive & $5(50.0)$ & $0(0.0)$ & $1(16.7)$ & $1(100)$ & $0(0.0)$ & $0(0.0)$ & $0(0.0)$ & \\
\hline
\end{tabular}

PTC: papillary thyroid cancer, PD-L1: programmed death-ligand 1, LVI: lymphovascular invasion,

\section{DISCUSSION}

It was reported that $77 \%$ of the patients who have total thyroidectomy and thyroid lobectomy due to PTC are female (15). The rate of female patients in the current sample was $72 \%$ and was compatible with the literature. In similar research, of the patients who had PTC, 70.5\% did not have cervical LNM, and $74.9 \%$ did not have lateral LNM (16). In the current study, $71.4 \%(n=25)$ of the patients did not have CI, and $80 \%(n=28)$ did not have LVI. Approximately less than $1 \%$ of patients with PTC make up these variants. PTC subtypes, including tall-cell, hobnail/micropapillary, columnar cell, diffuse sclerosing and solid variants. These variants of these tumours have a worse prognosis when compared to other types of PTC (17). In the current study, the PD-L1 expression was more severe in tall cell, oncocytic, and follicular type PTCs.

It is recommended to perform bilateral total thyroidectomy in patients with PTC and/or cervical and/or LLND and total thyroidectomy in patients with LNM (18). In addition to performing total thyroidectomy, 5 of the patients also underwent CLND and 2 of the patients also underwent CLND in addition to LLND. RAI for postoperative residual metastatic tissue in patients with PTC will reduce the risk of experiencing a recurrence. However, in relapse cases, the mortality rate is as high as $33-50 \%$ (19). In this study, postoperative RAI treatment was applied to all of the patients who had LNM.

HT is a T-cell-mediated autoimmune disease that affects the thyroid. HT produces autoreactive CD $4+\mathrm{T}$-cells, CD8 + cytotoxic T-cells and immunoglobulin G (IgG) autoantibodies. The production of large amounts of IL-1 $\beta$ in the thyroid glands in HT plays a role in its progression by causing massive thyrocyte apoptosis. Immunemediated apoptosis of tyrosides is guided by CD8 + cells. The receptors trigger the lymphocyte ligands on the target cells, released as soluble factors, and transmitted to the target cells. Although apoptosis is rarely seen in normal thyroid tissue, it increases significantly during HT (20). HT is a commonly seen form of chronic autoimmune thyroid disease, and the pathogenesis and prognostic effect of coexistence with PTC is a controversial condition. Some studies have reported an association between PTC and HT, which has been associated with a good prognosis, low relapse rate, and less aggressive disease $(21,22)$. However, some other researchers have observed that the coexistence of HT does not have such a protective effect on the results of a patient with PTC $(23,24)$. A recent metaanalysis of patients with PTC who had HT reported that female gender, tumour multifocality, but extrathyroidal extension, LNM were less common and associated with high relapse-free survival rates (25). Our main limitation is the low number of cases with papillary carcinoma that developed based on Hashimoto's thyroiditis in our study. Also reported was that the expression of PD-L1 increased in patients with PTC developing on a prediagnosis of HT. The expression of PD-L1 was observed to increase when combined with LNM in these patients (26). In the current study, the expression of PD-L1 was very weak or completely absent in patients with NG. However, the expression of PD-L1 was observed to be higher in patients who had HT than in the NG patients. Additionally, the PD-L1 expression was determined to have increased in patients with PTC compared to the other groups of patients. Although the increased mechanism of PD-L1 expression is not fully understood, it has been reported that cytokines released in the presence of inflammation induce PD-L1 expression (27). Oncocytic changes in the follicular epithelium in HT have been reported to have an association with an increase in the expression of PD-L1. In addition, PD-L1 expression was shown to increase in the presence of lymph node metastasis in the patients who had PTC coexisting with HT (26). In the current study, HT was found as a prediagnosis in 3 patients with PTC. One of these patients had LNM in addition to a follicular variant of PTC, and the expression of the PD-L1 score was 3+. The other two patients had no LNM, and the expression of PD-L1 score was 2+. 
Increased expression of PD-L1 in tumour cells in PTC was reported to show membranous staining in $6.1 \%$ of patients $(13,26)$. In the current study, the expression of PD-L1 was slightly lower than that in previous studies, and $4 \%$ membranous PD-L1 staining was detected. In studies using cytoplasmic staining to identify PD-L1 positivity, it was reported that PD-L1 expression was seen at a rate of $66.5-82.3 \%(28,29)$. In the current study, the cytoplasmic PD-L1 expression was $80 \%$.

Previous studies have shown that as tumour diameter increases, CI and LVI increase (30). We obtained similar results in our research. However, it was observed that PD-L1 expression did not increase significantly with the increase in tumor diameter. On the contrary, our study reveals that PD-L1 expression is higher in PTC variants (even if it is a smaller size in diameter than classical PTC) and tumours that cause LVI. Our study is valuable because it shows that anti-PD-L1 treatment will be beneficial in patients with metastatic lymph nodes despite neck dissection surgery and RAI treatment, especially in patients at risk for reoperation. PD-L1 has an essential role in determining how the PTC will be aggressive so that patients' prognosis can be predictable. Therefore, it is recommended that the suppression of PD-L1 can be used when treating PTC with a high PD-L1 expression (31).

Immunotherapy is a promising method that can be used to treat patients who have aggressive differential TC and ATC (32). PTCs occurring against a prediagnosis of HT may be resistant to standard treatment. The decision to use immunotherapy should be considered when treating metastatic PTCs. However, it should be remembered that destructive thyroiditis may occur after triggering thyroiditis, following the administration of cancer immunotherapy, monoclonal antibodies, or cancer vaccines $(33,34)$.

\section{CONCLUSION}

In conclusion, it was found that the expression of PD-L1 increased in the patients who had PTC. The expression of PD-L1 was observed to be higher in the patients who had PTC than in the patients who had HT. No significant difference was observed between the expression of PD-L1 and the tumour diameter and CI. However, a meaningful relationship was determined between the LVI and the expression of PD-L1. The PD-L1 expression and LVI were more severe in patients with follicular, tall cell, and oncocytic subtype PTC. It is necessary to conduct more studies to investigate the effect of PD-L1 expression on patient prognosis with PTC and its impact on patients who have PTC that develops with a prediagnosis of HT.

Ethics Committee Approval: The study was approved by the Clinical Researches Ethics Committee of Ballkesir University $(28.08 .2019,114)$.

Conflict of Interest: None declared by the authors.

Financial Disclosure: None declared by the authors.

Acknowledgements: None declared by the authors.

Author Contributions: Idea/Concept: SK, GT; Design: SK, GT; Data Collection/Processing: GT; Analysis/Interpretation: SK; Literature Review: SK; Drafting/Writing: SK; Critical Review: GT.

\section{REFERENCES}

1. Lim H, Devesa SS, Sosa JA, Check D, Kitahara CM. Trends in thyroid cancer incidence and mortality in the United States, 1974-2013. JAMA. 2017;317(13):1338-48.

2. Miller KD, Siegel RL, Lin CC, Mariotto AB, Kramer JL, Rowland JH, et al. Cancer treatment and survivorship statistics, 2016. CA Cancer J Clin. 2016;66(4):271-89.

3. Rahman GA. Extend of surgery for differentiated thyroid cancer: recommended guideline. Oman Med J. 2011;26(1):56-8.

4. Guerrero MA, Clark OH. Controversies in the management of papillary thyroid cancer revisited. ISRN Oncol. 2011;2011:303128.

5. Haugen BR, Alexander EK, Bible KC, Doherty GM, Mandel SJ, Nikiforov YE, et al. 2015 American Thyroid Association Management Guidelines for Adult Patients with Thyroid Nodules and Differentiated Thyroid Cancer: The American Thyroid Association Guidelines Task Force on Thyroid Nodules and Differentiated Thyroid Cancer. Thyroid. 2016;26(1):1-133.

6. Shin DS, Ribas A. The evolution of checkpoint blockade as a cancer therapy: what's here, what's next? Curr Opin Immunol. 2015;33:23-35.

7. Mahoney KM, Rennert PD, Freeman GJ. Combination cancer immunotherapy and new immunomodulatory targets. Nat Rev Drug Discov. 2015;14(8):561-84.

8. Chen DS, Irving BA, Hodi FS. Molecular pathways: next-generation immunotherapy--inhibiting programmed death-ligand 1 and programmed death- 1 . Clin Cancer Res. 2012;18(24):6580-7.

9. Chen G, Huang AC, Zhang W, Zhang G, Wu M, Xu $\mathrm{W}$, et al. Exosomal PD-L1 contributes to immunosuppression and is associated with anti-PD-1 response. Nature. 2018;560(7718):382-6.

10. Bastman JJ, Serracino HS, Zhu Y, Koenig MR, Mateescu V, Sams SB, et al. Tumor-infiltrating T cells and the PD-1 checkpoint pathway in advanced differentiated and snaplastic thyroid cancer. J Clin Endocrinol Metab. 2016;101(7):2863-73.

11. Pardoll DM. The blockade of immune checkpoints in cancer immunotherapy. Nat Rev Cancer. 2012;12(4):252-64.

12. Callahan MK, Postow MA, Wolchok JD. Targeting T cell co-receptors for cancer therapy. Immunity. 2016;44(5):1069-78.

13. Ahn S, Kim TH, Kim SW, Ki CS, Jang HW, Kim JS, et al. Comprehensive screening for PD-L1 expression in thyroid cancer. Endocr Relat Cancer. 2017;24(2):97-106.

14. Fadia M, Fookeerah P, Ali S, Shadbolt B, Greenaway T, Perampalam S. PD-L1 expression in papillary thyroid cancer with and without lymphocytic thyroiditis: a cross sectional study. Pathology. 2020;52(3):318-22.

15. James BC, Timsina L, Graham R, Angelos P, Haggstrom DA. Changes in total thyroidectomy versus thyroid lobectomy for papillary thyroid cancer during the past 15 years. Surgery. 2019;166(1):41-7.

16. Nie X, Tan Z, Ge M. Skip metastasis in papillary thyroid carcinoma is difficult to predict in clinical practice. BMC Cancer. 2017;17(1):702.

17. Baloch ZW, LiVolsi VA. Special types of thyroid carcinoma. Histopathology. 2018;72(1):40-52. 
18. DiMarco AN, Wong MS, Jayasekara J, Cole-Clark D, Aniss A, Glover AR, et al. Risk of needing completion thyroidectomy for low-risk papillary thyroid cancers treated by lobectomy. BJS Open. 2019;3(3):299-304.

19. Luster M, Aktolun C, Amendoeira I, Barczyński M, Bible KC, Duntas LH, et al. European Perspective on 2015 American Thyroid Association Management Guidelines for Adult Patients with Thyroid Nodules and Differentiated Thyroid Cancer: Proceedings of an Interactive International Symposium. Thyroid. 2019;29(1):7-26.

20. Chistiakov DA. Immunogenetics of Hashimoto's thyroiditis. J Autoimmune Dis. 2005;2(1):1.

21. Kwon JH, Nam ES, Shin HS, Cho SJ, Park HR, Kwon MJ. P2X7 receptor xxpression in coexistence of papillary thyroid carcinoma with Hashimoto's thyroiditis. Korean J Pathol. 2014;48(1):30-5.

22. Liang J, Zeng W, Fang F, Yu T, Zhao Y, Fan X. Clinical analysis of Hashimoto thyroiditis coexistent with papillary thyroid cancer in 1392 patients. Acta Otorhinolaryngol Ital. 2017;37(5):393-400.

23. Kurukahvecioglu O, Taneri F, Yüksel O, Aydin A, Tezel E, Onuk E. Total thyroidectomy for the treatment of Hashimoto's thyroiditis coexisting with papillary thyroid carcinoma. Adv Ther. 2007;24(3):510-6.

24. Del Rio P, Cataldo S, Sommaruga L, Concione L, Arcuri MF, Sianesi M. The association between papillary carcinoma and chronic lymphocytic thyroiditis: does it modify the prognosis of cancer? Minerva Endocrinol. 2008;33(1):1-5.

25. Lee JH, Kim Y, Choi JW, Kim YS. The association between papillary thyroid carcinoma and histologically proven Hashimoto's thyroiditis: a meta-analysis. Eur J Endocrinol. 2013;168(3):343-9.

26. Lubin D, Baraban E, Lisby A, Jalali-Farahani S, Zhang P, Livolsi V. Papillary thyroid carcinoma emerging from Hashimoto thyroiditis demonstrates increased
PD-L1 expression, which persists with metastasis. Endocr Pathol. 2018;29(4):317-23.

27. Kinter AL, Godbout EJ, McNally JP, Sereti I, Roby GA, O'Shea MA. The common gamma-chain cytokines IL-2, IL-7, IL-15, and IL-21 induce the expression of programmed death-1 and its ligands. J Immunol. 2008;181(10):6738-46.

28. Chowdhury S, Veyhl J, Jessa F, Polyakova O, Alenzi A, MacMillan C, et al. Programmed death-ligand 1 overexpression is a prognostic marker for aggressive papillary thyroid cancer and its variants. Oncotarget. 2016;7(22):32318-28.

29. Cunha LL, Marcello MA, Morari EC, Nonogaki S, Conte FF, Gerhard R, et al. Differentiated thyroid carcinomas may elude the immune system by $\mathrm{B} 7 \mathrm{H} 1$ upregulation. Endocr Relat Cancer. 2013;20(1):103-10.

30. Zhou B, Wei L, Qin J. Analyze and compare the predictors of ipsilateral central lymph node metastasis in papillary thyroid carcinoma with cT1a and cT1b stage. Asian J Surg. 2021:44(11):1357-62.

31. Shi RL, Qu N, Luo TX, Xiang J, Liao T, Sun GH, et al. Programmed death-ligand 1 expression in papillary thyroid cancer and its correlation with clinicopathologic factors and recurrence. Thyroid. 2017;27(4):537-45.

32. Moon S, Chung HS, Yu JM, Yoo HJ, Park JH, Kim DS, et al. Associations between Hashimoto thyroiditis and clinical outcomes of papillary thyroid cancer: A meta-analysis of observational studies. Endocrinol Metab (Seoul). 2018;33(4):473-84.

33. Corsello SM, Barnabei A, Marchetti P, De Vecchis L, Salvatori R, Torino F. Endocrine side effects induced by immune checkpoint inhibitors. J Clin Endocrinol Metab. 2013;98(4):1361-75.

34. Vita R, Guarneri F, Agah R, Benvenga S. Autoimmune thyroid disease elicited by NY-ESO-1 vaccination. Thyroid. 2014;24(2):390-4. 